\title{
Fish Community and Mining Activity in Serayu River Banyumas Residency
}

\author{
Susanto, Suwarno Hadisusanto
}

\begin{abstract}
The purpose of this research is to reveal and describe the quality of river waters and the fish comunity in Serayu river of Banyumas regency. The study was conducted using a survey method, with purposive random sampling technique. The study was conducted in Serayu river of Banyumas regency where three major rivers lead to it, namely Klawing river, Logawa river, and Tajum river. Fish sampled by spreaded net and handweb, with ten times sampling of each peripheral in each sampling point. Sampled fishes identified based on Kottelat et al. (1993) and verified on Biology Research Center, LIPI Cibinong and www.FishBase.org. Fish community structure analyzed by: Diverse, Cluster, and Multi Dimensional Scalling (MDS) of (Clarke and Warwick, 2001). The study found that water quality of physical and chemical parameters are in good condition. It includes temperature, flowrate, clarity, dissolved oxygen level, $\mathrm{pH}$, and plankton species variation in Serayu River Banyumas Residency. Most species and individual number on Serayu River Banyumas Residency are from Cyprinidae Family. Species diversity are in low condition but there are no dominancies found. Fish abundance are higher in downstream area than in upstream area, but fish species diversity are lower in downstream area than in upstream area of Serayu River Banyumas Residency. Long period of mining activity could badly affect river fish's life.
\end{abstract}

Index Terms: Abundance, Diversity, Fish Community, Mining Activity, Serayu River

\section{INTRODUCTION}

Serayu River Watershed is located in latitude 7o12'16', longitude 109054'47.4' (Wonosobo Regency Area) until latitude 7040'45.25' - 109o6'49,5', (Cilacap Regency Area). The river's upstream is come from Tuk Bimolukar that located in Dieng Plateu on Wonosobo Regency and ends up to Indian Ocean, Cilacap Beach. The length of the river, from the upstream to the downstream is $568,6 \mathrm{~km}$. Serayu River Watershed is one of the area that form a unit of water system that gather, keep, and distribute water to the sea through the main river, Serayu River. According to the administrative archieve Serayu River flows along five regencies : Wonosobo Regency, Banjarnegara Regency, Purbalingga Regency, Banyumas Regency, and Cilacap Regency (Anonymous, 2009).

Revised Manuscript Received on September 22, 2019.

Susanto, Department of Faculty of Teaching and Education, Muhammadiyah University of Purwokerto, Jawa Tengah, Indonesia.

Suswarno Hadisusanto, Department of Biology, Universitas Gajah Mada, Yogjakarta, Indonesia.
Along Serayu River could be found several small river that flow into it. There are at least nine tributaries from: Begaluh River, Tulis River, Merawu River, Kalisapi River, Pekacangan River, Gintung River, Klawing River, Logawa River, and Tajum River (Anonymus, 2009). Klawing, Logawa, and Tajum River are among the biggest tributaries in Banyumas Residency (Anonymous, 2013).

Resources usage could generate disturbances on certain level of ecosystem change, whether it will be realized or not. Resources usage without considering ecosystem principles could decrease environment quality, thus it will cause ecosystem order and environmental supporting capacity. People of Banyumas Residency, especially who stay in area along Serayu River use the resources, both biological resources and non-biological resources to fulfill their life stock or increase their wellfare. To use biological resources they do fishing, and for non-biological resources usage they do sand and stone mining. Even they unlikely understand what they did affect toward fish stock, growth, and species preservation.

Non-biological resources usage of sand and stone mining by Banyumas Residency people, especially those who stay along the Serayu River could affect river water quality. Class C mining activity happened on Serayu River Banyumas Residency nowadays are executed on certain position and in short period as mining permition granted by Local Government of Banyumas Residency. But class $\mathrm{C}$ mining activity as a whole, not only at Banyumas Residency, region along the river, which are Wonosobo, Banjarnegara, Purbalingga, Banyumas, and Cilacap, should be controlled or decreased in the matter of mining location or time. Long period of mining activity could badly affect river fish's life (Susanto, 2018). It caused fish community quality which live there. Biological fisheries resources management are integral part of water management comply with it's main purpose: optimal usage of water with keep environment. The final purpose are people welfare.

Problems in this researh are how biological and non-biological resources affect toward water quality in Serayu River and fish community which live there. Thus, to keep biological fisheries resources, it needs integrated management from fisheries sector and conservation.

\section{RESEARCH MethoD}

Research conducted on three major tributaries of Serayu River Banyumas Residency: Klawing River, Logawa River, and Tajum River. 
Fish sampling, physical chemical parameters data measuring, and plankton variation data sampling conducted for two years. First year of reseacrh start from October 2009 till July 2010, and second year of research start from October 2010 till July 2011 with three months sampling intervals. Sampling was conducted at both daytime $(08.00-12.00)$ and nighttime $(20.00-24.00)$.

Research conducted by survey method, with purposive random sampling technique. Fish sampling and water quality data measuring (physical chemical parameters and plankton variation data) conducted in each research location. Three station of sampling site decided for each research location: (1) $\pm 300 \mathrm{~m}$ before tributary, (2) $\pm 300 \mathrm{~m}$ after tributary, (3) $\pm 300 \mathrm{~m}$ before tributary on branch river. Three sampling point decided for each station: (1) sampling point at right side of the river, (2) sampling point at the middle of the river, (3) sampling point at left side of the river. Fish sampled by spreaded net and handweb, with ten times sampling of each peripheral in each sampling point. Sampled fishes identified based on Kottelat, et al. (1993) and verified on Biology Research Center, LIPI Cibinong and www.FishBase.org. Fish community structure analyzed by: Diverse, Cluster, and Multi Dimensional Scalling (MDS) of (Clarke and Warwick, 2001).

\section{RESUlt AND Discussion}

\section{River Water Quality}

Water quality on Serayu River Banyumas Residency could be analyzed from physical chemical parameters, which include: temperature, flowrate, clarity, dissolved oxygen, and $\mathrm{pH}$. Temperature analysis in Year I research (October $2009-$ Juli 2010) ranged on $27,72-29,63{ }^{\circ} \mathrm{C}$ with average temperature $28,28 \pm 0,342{ }^{\circ} \mathrm{C}$ and inYear II research (October 2010 - Juli 2011) ranged on $27,63-29,86{ }^{\circ} \mathrm{C}$ with average temperature $28,51 \pm 0,724^{\circ} \mathrm{C}$. Flowrate in Year I research ranged on $0,26-0,87 \mathrm{~m} / \mathrm{s}$ with average flowrate $0,52 \pm 0,207 \mathrm{~m} / \mathrm{s}$ and in Year II research ranged on $0,27-$ $0,98 \mathrm{~m} / \mathrm{s}$ with average flowrate $0,54 \pm 0,195 \mathrm{~m} / \mathrm{s}$. Dissolved oxygen analysis result in Year I research ranged on 5,92 8,45 ppmwith average $6,88 \pm 0,782 \mathrm{ppm}$ and in Year II ranged on 4,20 - 8,23 ppm with average 6,04 \pm 1,241 ppm. Acidity level $(\mathrm{pH})$ in Year I research ranged on 6,72 - 7,22 with average 6,97 $\pm 0,183$ and in Year II ranged on 6,72 7,22 with average 6,97 $\pm 0,183$.

Physical parameter analysis results of water quality done based on sampling time are as follows. Temperature analysis in daytime sampling ranged on $27,61-28,99{ }^{\circ} \mathrm{C}$ with average temperature $28,25 \pm 0,51{ }^{\circ} \mathrm{C}$ and in nighttime sampling ranged on $27,39-28,96{ }^{\circ} \mathrm{C}$ with average temperature $28,33 \pm 0,49^{\circ} \mathrm{C}$. Flowrate in daytime sampling ranged on $0,29-0,82 \mathrm{~m} / \mathrm{s}$ with average flowrate $0,54 \pm 0,17$ $\mathrm{m} / \mathrm{s}$ and in nighttime sampling ranged on $0,21-0,97 \mathrm{~m} / \mathrm{s}$ with average flowrate $0,53 \pm 0,23 \mathrm{~m} / \mathrm{s}$. Clarity in daytime sampling ranged on 17,890 - 84,33 with average flowrate $38,10 \pm 1,18 \mathrm{~cm}$.

Chemical parameter analysis results of water quality done based on sampling time are as follows. Dissolved oxygen analysis result in daytime sampling ranged on 4,82 - 7,80 ppm with average $6,29 \pm 1,01 \mathrm{ppm}$ and in nighttime sampling ranged on 4,34 - 8,24 ppm with average $6,44 \pm 1,33$ ppm. Acidity level $(\mathrm{pH})$ in daytime sampling ranged on 6,56 - 7,28 with average $6,94 \pm 0,21$ and in nighttime sampling ranged on $6,56-7,17$ with average $6,96 \pm 0,18$.

Plankton that sampled during research then identified for their species. Identification result shows that there are high variations of plankton species on Serayu River Banyumas Residency. During research there are 109 plankton, 47 Families, 23 Ordos identified. Those number includes Phytoplankton of 97 Speies, 36 Families, 18 Ordos, and Zooplankton of 12 Species, 11 Families, 5 Ordos. Based on PPRI (2001); Susanto (2018); Susanto (2017) and (Krebs, 2009) the condition as described above on Serayu River Banyumas Residency are in good condition and suitable for fishes' life.

\section{Fish Community}

This research caught 3.871 fish of 29 Species, 20 Families, and 11 Ordos. Most caught fish on Year I and Year II of research are from Cyprinidae Family, with fish number caught in Year I and Year II consecutively: 794 fishes(55,23 $\%)$ and 941 fish $(38,65 \%)$. Most least caught fish on Year I research are from Anguilloidae Family, with two fishes caught $(0,13 \%)$, and most least caught fish on Year II reseach are from Clariidae Family and Synbhrachidae Family with one fish caught on each Families $(0,03 \%$ and $0,06 \%$ each Family consecutively). Full result of the data described on Figure1 and Figure2 as follow. Highest fish abundance Serayu River on Year I and Year II located in Location Three (Tajum River tributaries on Serayu River), the most downstream region of Serayu River Banyumas Residency. Abundance average are 103,17 pcn on Year I research and 120,83 on second year. Abundance average on Location 1 (Klawing River tributaries on Serayu River) are 54,75 pcn on Year I research and 81,58 on second year. Abundance average on Location 2 (Logawa River tributaries on Serayu River) are 40,42 pcn on Year I research and 56,08 on second year.

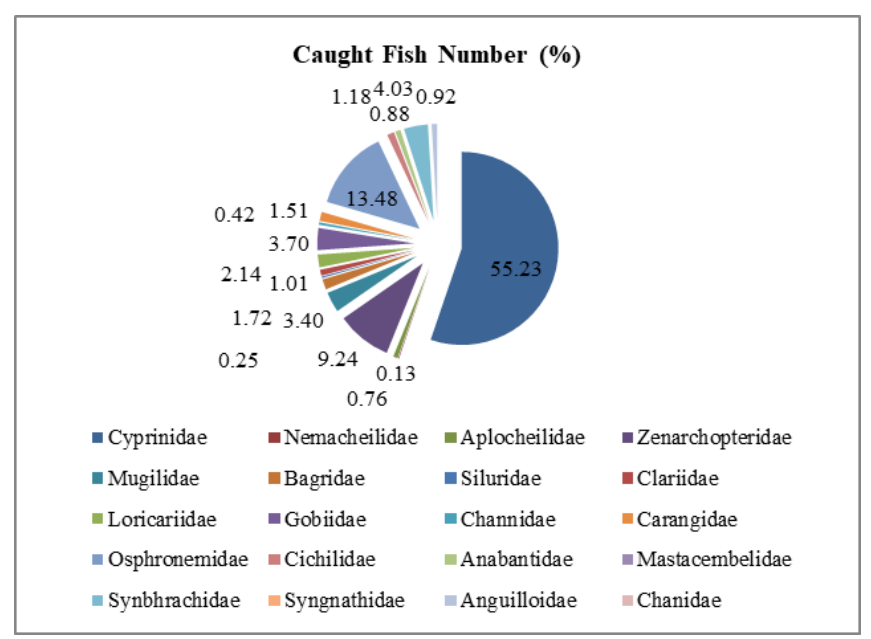

Fig 1. Caught Fish Number Based on Family in Percentage of Year I Research 
International Journal of Recent Technology and Engineering (IJRTE) ISSN: 2277-3878, Volume-8 Issue-2S9, September 2019

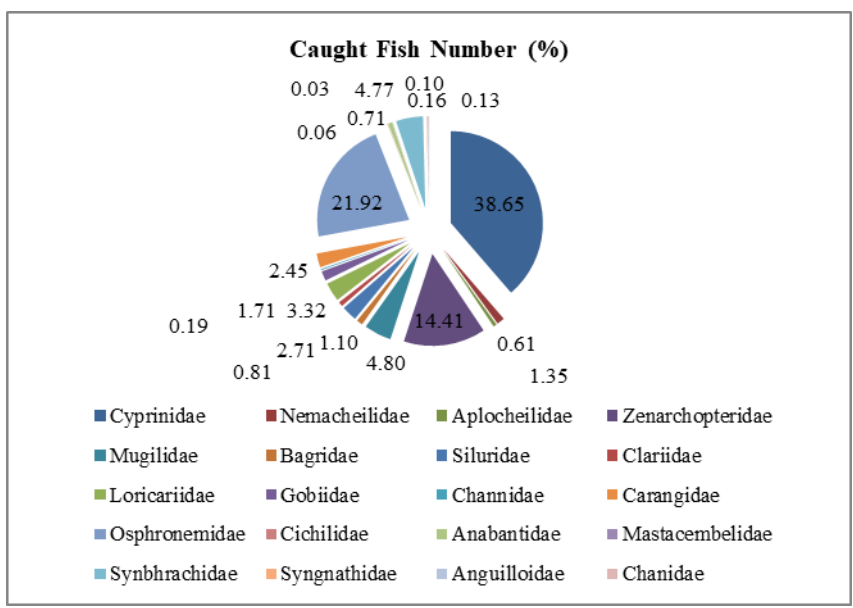

Fig 2. Caught Fish Number Based on Family in Percentage of Year I Research

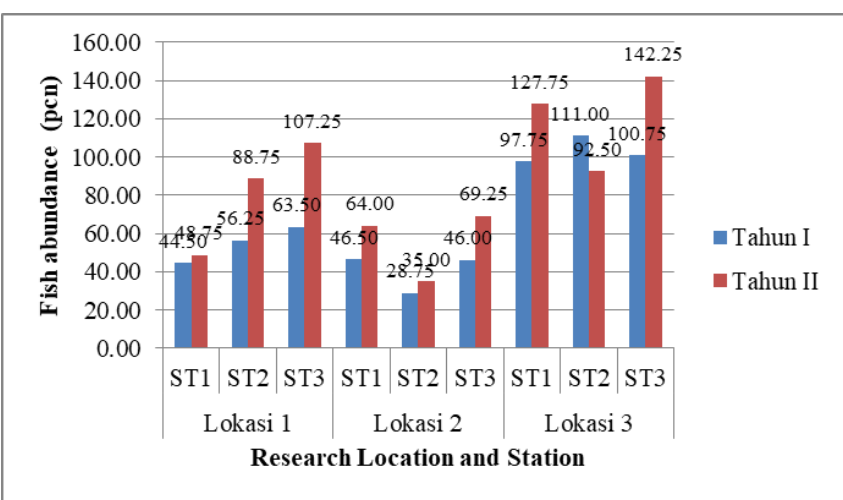

Fig 3. Fish Abundance Average per Caught Number (pcn) on Year I and Year II Research

Most least individual number caught are from location two. Fish abundance are affected by environmental condition, thus differences on river environmental condition could differs fish abundance (Sumitra and Rozi, 2018); (Wahyuni and Zakaria, 2018); Muslih et al. (2014); Morán-López (2012); (Muthmainnah, 2010).

Shannon-Wienner abundance index value on Year I ranged at $1.364-2.395$ with average $1.899 \pm 0.396$, and on Year II ranged at 1,452 - 2,284 with average 1,843 \pm 0,296.Simpson domination index value on Year I ranged at $0,0928-0,4581$ with average $0,2462 \pm 0,1372$, and on Year II ranged at 0,1338 - 0,3457 with average 0,2731 \pm 0,0763.Diverse analysis reveal fish species diversity and domination are in low condition, wether it based on Year I and Year II sampling or daytime and nighttime sampling. This result are as shown as Table 1 and Table 2 below. The condition means even there are no domination found, fish existence in Serayu River Banyumas Residency are in endangered condition. Dendogram of Cluster analysis result and MDS analysis result are showing the same result as shown as Fig 4,and 5.
Table 1 Fish Community (Diversity) Diverse Analysis Result on Year I and II.

\begin{tabular}{ccccccc}
\hline \multirow{2}{*}{ Station } & \multicolumn{3}{c}{ Year I } & \multicolumn{3}{c}{ Year II } \\
\cline { 2 - 7 } & S & N & $\mathbf{H}^{\prime}$ & $\mathbf{S}$ & $\mathbf{N}$ & $\mathbf{H}^{\prime}$ \\
\hline L1S1 & 16 & 45 & 2,065 & 14 & 49 & 1,672 \\
L1S2 & 15 & 56 & 2,395 & 16 & 89 & 2,284 \\
L1S3 & 12 & 64 & 1,362 & 18 & 107 & 2,125 \\
L'2S1 & 17 & 47 & 2,248 & 14 & 64 & 1,585 \\
L2S2 & 16 & 29 & 2,305 & 12 & 35 & 1,882 \\
L2S3 & 16 & 46 & 2,024 & 15 & 69 & 1,920 \\
L3S1 & 18 & 98 & 1,907 & 17 & 128 & 1,452 \\
L3S2 & 20 & 111 & 1,422 & 16 & 93 & 1,522 \\
L3S3 & 18 & 101 & 1,364 & 19 & 142 & 1,759 \\
Entire Location & 26 & 66 & 2,105 & 29 & 86 & 2,231 \\
\hline
\end{tabular}

Remarks : $\quad \mathrm{S}=$ spesies count, $\mathrm{N}=$ individual count average, H' Shanon Wienner index

Table 2 Fish Community (fish domination) Diverse Analysis Result on Year I and II

\begin{tabular}{ccccccc}
\hline & \multicolumn{3}{c}{ Year I } & \multicolumn{3}{c}{ Year II } \\
\cline { 2 - 7 } IV. StATION & S & N & D & S & N & D \\
\hline L1S1 & 16 & 45 & 0,1896 & 14 & 49 & 0,2453 \\
L1S2 & 15 & 56 & 0,0928 & 16 & 89 & 0,1338 \\
L1S3 & 12 & 64 & 0,3947 & 18 & 107 & 0,1568 \\
L2S1 & 17 & 47 & 0,1367 & 14 & 64 & 0,3220 \\
L2S2 & 16 & 29 & 0,1013 & 12 & 35 & 0,1873 \\
L2S3 & 16 & 46 & 0,1839 & 15 & 69 & 0,2150 \\
L3S1 & 18 & 98 & 0,2319 & 17 & 128 & 0,3110 \\
L3S2 & 20 & 111 & 0,4421 & 16 & 93 & 0,3457 \\
L3S3 & 18 & 101 & 0,4581 & 19 & 142 & 0,2885 \\
Entire Location & 26 & 66 & 0,2308 & 29 & 86 & 0,1658 \\
\hline
\end{tabular}

Remarks : $\mathrm{S}=$ spesies count, $\mathrm{N}=$ individual count average, $\mathrm{D}=$ Simpson domination index

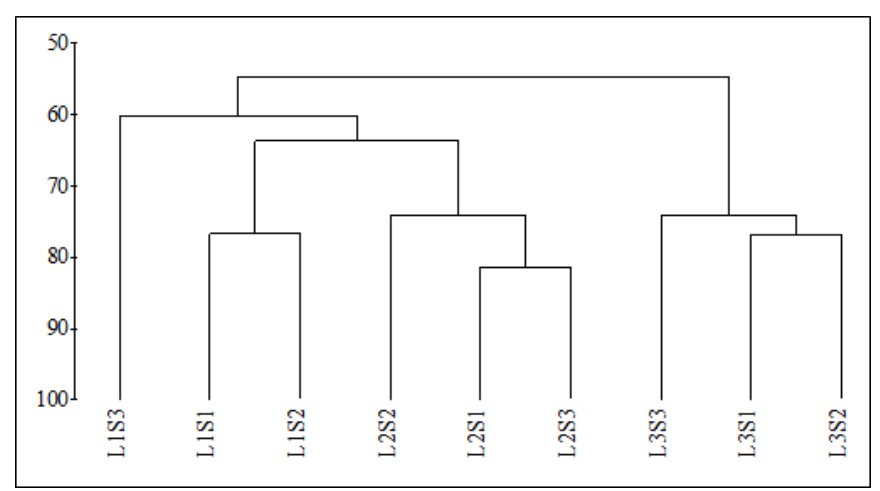

Fig 4. Fish Community Cluster Analysis Dendogram Result on Year I 


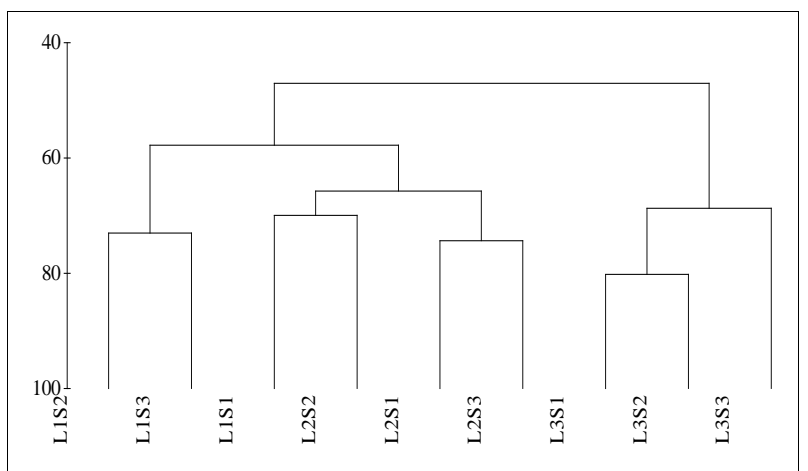

Fig 5. Fish Community Cluster Analysis Dendogram Result on Year II

Location one (Klawing tributary) and location two (Logawa tributary) fish community have higher similiarity index than both of it compared to location three (Tajum tributary) fish community. Location one - location two situation and water condition similiarity are reason for both fish community similiarity. Location three have different situation and condition compared to location one and two with open region. It caused the significant differences of location three fish community compared to location one and two. Upstream and midstream fish community of Serayu River Banyumas Residency show insignificant differences.

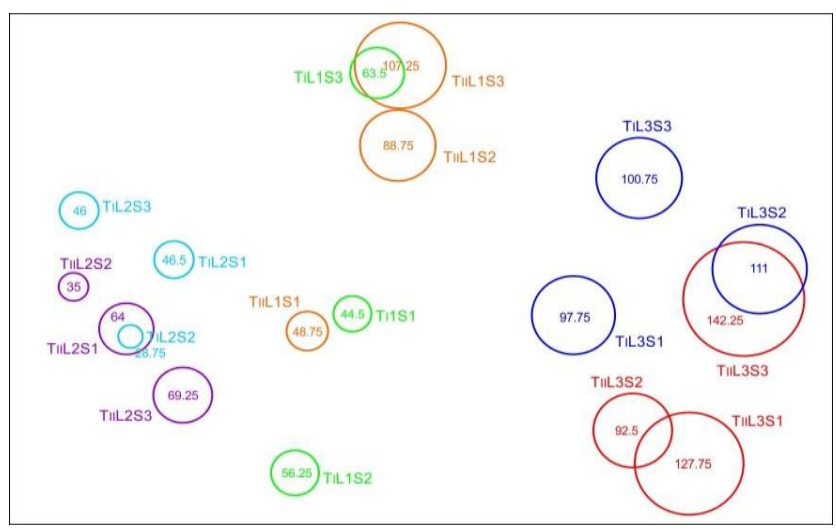

Fig 6. Fish community MDS analysis on Year I and Year II

\section{Mining ACtivity}

During research, rainfall are in high category with average: $606,57 \mathrm{~mm}$ with highest rainfall on October 2010 : $914 \mathrm{~mm}$. research done from October 2009 till July 2011 in between 24 months, only on June 2011 with six days of rainfall at $111 \mathrm{~mm}$ and on July 2011 with one day of rainfall at $3 \mathrm{~mm}$. another 22 month have rain days averaged between $19-30$ days at $338-914 \mathrm{~mm}$, even at 2010 are rainy all year long (Anonyomus, 2013).

It caused water turbidity become high and low water clarity, and water debit of Serayu River Banyumas Residency also at high level. High level of turbidity already occurred at upstream region of Serayu River, region before Banyumas Residency area. High turbidity level mean dissolved particle are in high amount. It could decrease river fish visibility and disturb their food gathering activity, reproduction, and maintaining offsprings and juveniles. Water quality analysis result based upon PPRI (2001) and expert opinions as described before, Serayu River Banyumas Residency are still in good and suitable condition for fish life.

Class C mining activity happened on Serayu River Banyumas Residency nowadays are executed on certain position and in short period as mining permition granted by Local Government of Banyumas Residency. But class C mining activity as a whole, not only at Banyumas Residency, region along the river, which are Wonosobo, Banjarnegara, Purbalingga, Banyumas, and Cilacap, should be controlled or decreased in the matter of mining location or time. Long period of mining activity could badly affect river fish's life (Susanto, 2018).

\section{CONCLUSION}

Conclusion based on result and discussions are:

1. Water quality of physical and chemical parameters are in good condition. It includes temperature, flowrate, clarity, dissolved oxygen level, $\mathrm{pH}$, and plankton species variation in Serayu River Banyumas Residency.

2. Most species and individual number on Serayu River Banyumas Residency are from Cyprinidae Family. Species diversity are in low condition but there are no dominancies found.

3. Fish abundance are higher in downstream area than in upstream area, but fish species diversity are lower in downstream area than in upstream area of Serayu River Banyumas Residency.

4. Long period of mining activity could badly affect river fish's life.

\section{SUGESSTION}

Several suggestion related to the research about fish community in Serayu River Banyumas Residency as a follow up are:

1. Integrated cooperative between related authorities about Serayu River management, such as Local Goverment, Water Management, College, and society on water resource usage, management, and fish resources on Serayu River sustainably.

2. Local Government which their area flows Serayu Rivers should publish Local Act that organize fish catching, for example:

a. Fish size that allowed to catch, length and weight as per species.

b. Fishing time, as prohibition of fishing at breeding time at mangsa kapapat (end of draught and beginning of wet season).

c. Fishing peripheral, which selectively catch, for example net with minimum net size of three centimeters or web with minimum size of one centimeter net size and prohibit usage of massive fishing, e.g., poison, explosive, and electrical. 
3. Local Goverment or Central Goverment are expected to decide protected region to sustain fish species diversity. Protected region are in Serayu River where it frequently used by fish for breeding region, e.g. upstream location on Serayu River Banyumas Residency, in Somagede Sub-Residency.

\section{REFERENCES}

1. Anonymous. 2009. Konsep Peraturan Gubernur Peruntukan Air dan Pengelolaan Kualitas Air Sungai Serayu. Provinsi Jawa Tengah: Peraturan Gubernur Provinsi Jawa Tengah. www.blh.jawatengah.go.id.

2. Anonymous. 2013. Sungai Serayu : Curah Hujan dan Debit Air. Balai Pengelolaan Sumber Daya Air Serayu Citanduy.Dinas Pengelolaan Air Provinsi Jawa Tengah.

3. Clarke, K.R. and R.M. Warwick. 2001. Changes in Marine Communities : an Approach to Statistical Analysis and Interpretation, $2^{\text {nd }}$ edition, PRIMER-E: Plymouth, London.

4. Kottelat, M., J.A. Whitten, S.N. Kartikasari, Wirjoatmojo. 1993. Ikan Air Tawar Indonesia Bagian Barat dan Sulawesi.Edisi Dwibahasa Inggris - Indonesia.Periplus Edition. Jakarta.

5. Krebs C. J. 2009. Ecology, the Experimental Analysis of Distribution and Abundance. Harper and Row Publisher. New York.

6. Morán-López, R., J. L. Pérez-Bote, E. Da Silva, A. B. P. Casildo. 2012. Hierarchical large-scale to lokal-scale influence of abiotic factors in summer-fragmented Mediterranean rivers: structuring effects on fish distributions, assemblage composition and species richness. Hydrobiologia, 696 : 137 - 158.

7. Muslih, Khoirul, Enam M. Adiwilaga and Soeryo Adiwibowo. 2014. Karakteristik Habitat dan Keanekaragaman Ikan Air Tawar Sungai Menduk yang Mendapat Pengaruh Penambangan Timah di Kabupaten Bangka. Akuatik. 8 (2): 17-23.

8. Muthmainnah, D. 2010. Komposisi Jenis Ikan di Sepanjang Aliran Sungai Musi. Prosiding Seminar Nasional Biologi : Biodiversitas dan Bioteknologi Sumberdaya Akuatik. R.E. Prabowo, E.R. Ardli, M.H. Sastranegara, W. Lestari, G. Wijayanti, A. Nuryanto (Ed). Fakultas Biologi Universitas Jenderal Soedirman. Purwokerto.

9. PPRI (Peraturan Pemerintah Republik Indonesia). 2001. Nomor 82 Tahun 2001 tentang: Pengelolaan Kualitas Air dan Pengendalian Pencemaran Air. Sekretariat Negara Replublik Indonesia. Jakarta.

10. Samitra, D. dan Rozi, Z. F. 2018. Keanekaragaman Ikan di Sungai Kelingi Kota Lubuk Linggau. Jurnal Biota. 4 (1) : 1-6.

11. Susanto. 2017. Ekologi : Konservasi Sumberdaya Hayati. UMP Press. Purwokerto.

12. Susanto. 2018. Ikan dan Ekosistem Sungai (Komunitas Ikan di Sungai Serayu Wilayah Kabupaten Banyumas). Pustaka Belajar. Yogyakarta.

13. Wahyuni, T. T. and Zakaria, A. 2018. Keanekaragaman Ikan di Sungai Luk Ulo Kabupaten Kebumen. Biosfer. 35 (1) : 23-28.

\section{AUTHORS PROFILE}

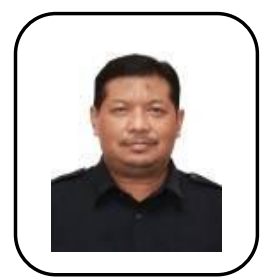

Dr. Susanto is a Senior Lecturer at the FKIP UMP (Faculty of Education and Teacher Training, Muhammadiyah University of Purwokerto), Jalan Raya Dukuhwaluh, Purwokerto City, Central Java, Indonesia. He is teaching in the Biology Education Study Program. Dr. Susanto background is in Biology, Animal Ecology and Ecology. For academic purposes, the author can be contacted via e-mail at: susanto280266@gmail.com

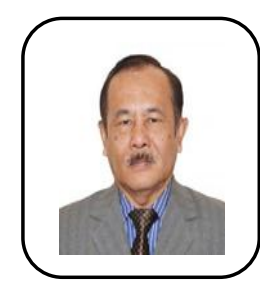

Prof. Dr. Suwarno Hadisusanto is a professor at the Faculty of Biology, Universitas Gajah Mada, Indonesia. His expertise and publication include research freshwater ecology limnology and environment pollution. For academic purposes, the author can be contacted via e-mail at : suwarnohs@ugm.ac.id 